\title{
Tartalomalapú nyelvtanulás és -oktatás a korai szakaszban: innovatív tananyagok, és -eszközök, tanulásszervezési formák és módok
}

\section{Görcsné Muzsai Viktória}

NYME Széchenyi István Egyetem Apáczai Csere János Kar, Idegen Nyelvi Intézeti Tanszék, Győr

\begin{abstract}
A NYME Apáczai Kar Idegen Nyelvi és Irodalmi Intézeti Tanszéke húszöt éves fennállása óta folyamatosan segíti és müveli is az innovatív gondolatok születését, megvalósulását. Irányadónak tekintjük a Közös Európai Referenciakeret (KER 2000) ajánlásait, amelyek a tartalom- és kompetenciaalapú (CLIL=Content and Language Integrated Learning) nyelvi közvetítésre és többnyelvüségre, az interkulturális tanulásra, a használható nyelvtudásra helyezik a hangsúlyt. Az előadás bemutat néhányat az osztrák-magyar bilaterális EdTWIN projektben (2008-2011) kifejlesztett, kipróbált és használatra közreadott innovatív tananyagok, és -eszközök, valamint tanulásszervezési formák és módok közül (pl. portfólió az angol/magyar/német nyelv tanulásához, modultankönyv magyar mint idegen nyelv tanulásához, multimédia-támogatottságú nyelvi mühely, mikro- és projekttanítás), melyeket szervesen beépítettünk az angolnémet választott müveltségterületen folyó tanitóképzési tevékenységünkbe.
\end{abstract}

Kulcsszavak: innovatív tananyagok, innovatív eszközök, korai nyelvoktatás, tartalomalapú tanulásszervezési formák, tartalomalapú tanulásszervezési módok

\section{A győri tanítóképzés 235 éve dióhéjban: a NYME Apáczai Kar és az Idegen Nyelvi és Irodalmi Intézeti Tanszék rövid bemutatása}

Az Apáczai Csere János Kar jogelődjének a Ratio Educationis rendelkezése alapján az 1778. július 1-jén Győrött megnyílt első mesterképző tanfolyamot tekinti. Így büszkén mondhatjuk, hogy 235 éve létezik tanítóképzés Győrben. A tanítóképzés az 1869/70-es tanévtől vált háromévessé, a négyéves tantervű képzés pedig 1893-ban kezdődött. A fejlödés föbb állomásait jelentette a képzés felsőfokúvá (1959), illetve 1975-töl főiskolai szintüvé válása. A győri tanítóképzés 200. évfordulója alkalmából 1978-ban a főiskola felvette a nagy iskolaszervező tudós pedagógus, Apáczai Csere János nevét. 1990-től jelentős tartalmi és szerkezeti változások történtek a főiskola életében. Az 1990/91-es tanévtől angol és német, 1991-től olasz és 1992-től francia nyelven is megindult az idegennyelv-oktató tanítóképzés. 1992-ben Dunaszerdahelyen és Révkomáromban is megkezdte a főiskola szlovákiai magyar anyanyelvű tanítók képzését. 1996-tól szociálpedagógia, 2001/02-től tanulásban akadályozottak pedagógiája tanári, felsőfokú idegenforgalmi szakmenedzser, valamint szálloda és vendéglátó szakos 4 éves közgazdászképzéssel, majd andragógia, gyógypedagógia, rekreációszervező és egészségfejlesztő szakirányokkal bővült a képzési paletta. A kar 2006-tól áttért a bolognai típusú BA képzésre.

A 25 éve alakult Idegen Nyelvi és Irodalmi Intézeti Tanszék egyrészt klasszikus lektorátusi feladatok keretében turizmus-vendéglátás, gyógypedagógia és andragógia szakon szaknyelvi képzést biztosít és államilag elismert nyelvvizsgára készíti fel a kar hallgatóit angol, francia, német, olasz, orosz és spanyol nyelvböl, kínálatunkban szerepel a japán, a lovari és a magyar mint idegen nyelv is. Másrészt a tanítóképzésben a választott idegen nyelvi múveltségterületen (VMT) angol és német nyelvpedagógiai képzést végez. A VMTtanúsítvány birtokában a tanítódiplomát szerzett hallgatók 1-6. osztályban taníthatják a 
választott idegen nyelvet. A tanszék 22 európai országban rendelkezik szakmai és tudományos kapcsolattal, ERASMUS mobilitásprogram és nemzetközi EU által támogatott projektek keretében küld hallgatókat és oktatókat a partner egyetemekre és főiskolákra és fogad onnan érkezőket. Tudományos tevékenységét - többek között - a korai nyelvi fejlesztés, a gyermeki nyelvelsajátítás és nyelvi kompetenciafejlesztés, a többnyelvűség, inter- és multikulturalitás területeken fejti ki. 17 oktatónk közül 6 rendelkezik PhD-fokozattal, 1 fő közülük habilitált, 5 fő doktoranduszként vesz részt a képzésben, 2 mestertanár és 4 nyelvi lektor támogatja nyelvoktató munkánkat. A korai idegennyelvi-fejlesztés elméleti és gyakorlati szakembereinek jelenléte megnyugtató hátteret biztosít a tanítóképzés választott (angol és német nyelvi) mủveltségterületein való szakmai munkánkhoz.

\section{Nyelvpedagógiai tendenciák, tényezők és filozófia}

Az idegennyelv-oktatásban az utóbbi 50 évben 3 meghatározó fejlesztési tendencia érvényesült: 1960/70-es években jellemzően a kommunikatív szemlélet honosodott meg, amely a mindennapok pragmatikus nyelvhasználatát helyezte előtérbe az „ünnepi nyelvvel" szemben. Ezt követte az 1980/90-es évektöl kezdődő interkulturális szemléletmód, amelynek nyomán mára bebizonyosodott, hogy a nyelvtanulás a személyiség fejlődését támogatja, a látásmódot és tájékozottságot tágítja, és a másik személye, nyelve és kultúrája iránti toleranciára nevel. Az 1990/2000-as évektől beszélhetünk az ún. tartalomés kompetenciaalapú nyelvoktatásról, amelynek filozófiája szerint a nyelvtanulás akkor a leghatékonyabb, ha a nyelv nem tárgy, hanem a tartalom átadására szolgáló eszköz: "Content and Language Integrated Learning" "Language is best learned when it is the medium, not the object of instruction" (Cloud, 1998. 113. o.). Ebben az értelemben az idegen nyelvet a lehető legtermészetesebb módon be kell ágyazni a kontextusba, azaz: az „Idegen nyelv mint munkanyelv" „Fremdsprache als Arbeitssprache“, "Content and Language Integrated Learning“ (CLIL) szerepel. Reinhold Freudenstein a következőt állítja a modern nyelvtanulás és -tanítás hatékonyságáról: "It is well-known from empirical studies as well as from practical experience, that best results from foreign language learning can be expected if languages are used to teach content rather than foreign language material. Foreign languages should be offered as early as possible (kindergarten, preschool, primary level)" (Freudenstein, 1997. 74. o.). Ennek megfelelően az idegen nyelvekkel lehetőleg már az óvodában, illetve az általános iskolában meg kell kezdeni az ismerkedést. A nyelvtanulás akkor a leghatékonyabb, ha nemcsak intézményes keretek között szervezett, hanem az új nyelv saját csatornáin egyúttal egy szak tanítási tartalmait és a szükséges nyelvi készségeket közvetíti és figyelembe veszi a tanuló korát, tudásszintjét, hajlandóságát és érdeklődését. A nyelvtanulás így a tudás és készségek együttes bevetésével kétcsatornás tanulás formájában valósul meg (lásd 1. ábra). 


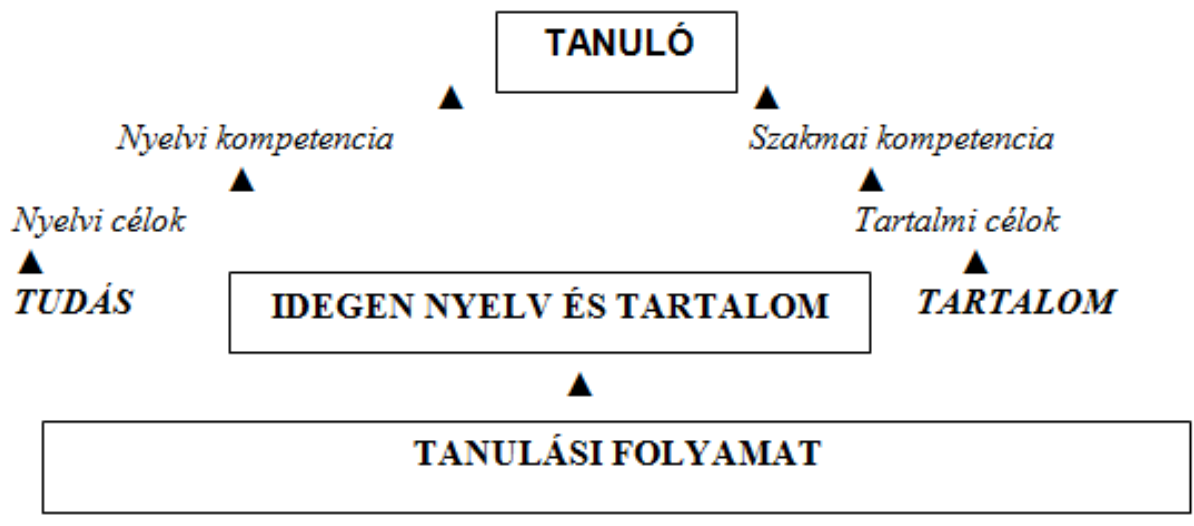

1. ábra: Kétcsatornás nyelvtanulás

Ez azt jelenti, hogy a tartalomalapú nyelvoktatás) az iskolai tanulás végére magasabb szintű nyelvi kompetenciához vezet, mint a szokásos intézményes nyelvtanulás. Ezáltal a nyelvi kontaktidő meghosszabbodik, az egyes szakterületek tartalma az új nyelvben rövid szekvenciákban jelenik meg anélkül, hogy a szakmai oktatás ideje lényegesen csökkenne.

A nyelvpedagógiai kérdések közül említést érdemel a legutóbbi kutatások egyik fontos vetülete: a nyelvtanulás/-tudás sikerességét befolyásoló tényezők kérdése. A sikert alapvetően három fontos tényező befolyásolja. Közülük leginkább a pedagógiai kérdésekröl (mint taneszközök, módszerek, tananyag, nyelvtanítási szemlélet) esik szó a szakemberek és a téma iránt érdeklődők körében. Sokkal kevesebb figyelmet kapnak a nyelvtanulást segítő, ún. elönyös adottságok: a) egy ország földrajzi-társadalmi helyzete: több államnyelv és nyelvi heterogenitás jelenléte, fejlett gazdaság előnyei, társadalmi és egyéni mobilitás, b) a nyelv tanulását és oktatását támogató környezet, c) releváns nyelvoktatás-politikai célok kitüzése és következetes megvalósítása. Szinte teljesen elhanyagolt az egyéni attitüd kérdése, azaz az egyes tanuló nyelvtanuláshoz való viszonya. Pedig fontos lenne a nyelvtanulást a jövőbe való - rentábilis időt és költséget jelentő és a kockázatvállalást mint egészséges kihívást is tartalmazó - befektetésként, valamint kapcsolatokat és élményeket hozó, a személy életét gazdagító és nem megkeserító élményként és örömforrásként értelmezni (Einhorn'1, 2012. 22-25. o.)

A hatékony nyelvtanulás és -tanítás és előfeltételeinek kérdéséhez még egy fontos kérdést szükséges tisztázni, jelesen a nyelvtanítási filozófia alapvetését. A hagyományos pedagógiai tervezés középpontjában álló „mit tanítsak?” kérdés helyett és mellett a mai igények szerint előtérbe kell kerülnie a „kit tanítok?” és „hogyan tanítok?” (azaz a tanuló és a tanulásszervezés) kérdésének. Egy pedagógus értelmezési példája alapján a következőről van szó: „ahelyett, hogy azon gondolkoznék, melyik újságcikket vagy melyik oldalon található szöveget használjam, valójában azon gondolkozom, hogy ki a nyelvtanuló, mik az ő nyelvvel kapcsolatos céljai, és hogyan támogassam őt nyelvtanárként a leghatékonyabban tanulásának tanórai megszervezésével és tanórán kívüli instruálásával e célok elérésében. (...) ehhez sok energia, kreativitás és kellö nyelvtanári kompetencia szükséges. Hazai és külföldi nyelvész-pedagógus szakemberek (Szépe, 2010. 84. o., Freudenstein, 1997. 75-77. o., Günther, 2005. 41-43. o. és Peltzer-Karpf, 1998. 69-70. o.) szerint egy új nyelv sikeres elsajátításához a következő feltételek szükségesek:

\footnotetext{
1 A fenti kérdésekre vonatkozó nemzetközi szakirodalmi jegyzék található Einhorn Ágnes hivatkozott cikkének
} 35. oldalán. 
- a nyelvtanár magas szintű szakmai (idegen nyelvi és szociális) kompetenciája

- az inputok optimális minősége és mennyisége

- a nyelvtanítási formák és anyagok közelítése az elsőnyelvi - elsajátítás alapmodelljéhez

- „a nyelvtudás mindig kontextus-függő, lényege az adott szituációban való helytállás" elfogadása.

\section{Innovatív tananyagok és eszközök}

A továbbiakban nézzük meg, milyen innovatív tananyagok és -eszközök kínálkoznak az osztrák-magyar határokon átívelő 2008-2011 között megvalósított EdTWINprojekt ${ }^{2}$ keretein belül a kétcsatornás tartalom- és kompetenciaalapú nyelvtudás támogatására a fenti fejezetben kifejtett nyelvpedagógiai tendenciák, tényezők és filozófia figyelembevételével ${ }^{3}$.

\section{1. „Kincskeresők, kalandra fel!” - Modultankönyv a magyar mint idegen nyelv oktatásához}

A modultankönyv nyelvünkből és kultúránkból kínál kóstolót az érdeklődők számára. Bécsben élő és dolgozó szerzők, magyar anyanyelvű lektor, valamint illusztrátor és tördelőszerkesztő kooperációjában készült fiataloknak (ua. alkalmas idősebbek magyar nyelvvel való első találkozására is). A tananyag a nyelvoktatás legújabb eredményeit figyelembe véve kíván a tanulóknak a magyar nyelvi környezetben való eligazodáshoz segítséget nyújtani, de nem követi a hagyományos tankönyvek felépítését: olyan projektek, nyelvkurzusok vagy workshopok keretein belül alkalmazható, ahol az elsődleges cél nem a magyar nyelvtan aprólékos megismertetése, hanem bizonyos témákhoz tartozó nyelvi szituációk, lehetséges kifejezések és mondatok elsajátíttatása. A fiatalok nem szavakat, hanem „nyelvi paneleket“, rövid mondatokat tanulnak, a tanultakat pedig például egy mini kurzust követő magyarországi kirándulás során ki is próbálhatják.

Az egyes modulok oldalai és a fejezetek többé-kevésbé függetlenek egymástól, pontosabban minden oldalt és fejezetet egymástól függetlenül, önállóan is fel lehet használni. Ez az elv mutatkozik meg a könyv formai kivitelezésében is: a könyv lapjai perforáltak, hogy a tanár könnyen kivehesse azokat az oldalakat, amelyeket fel szeretne használni, és a kiválasztott lapokat gyorsan és egyszerűen sokszorosíthassa. A könyv nagy szabadságot biztosít a tanár számára. A tanár dönti el, mit és milyen mértékben tanít, melyik témában mélyül el részletesebben, melyiket említi csak, és melyiket hagyja ki. Noha arra törekedtünk, hogy a könyv fejezetei, alfejezetei valóban egymástól függetlenül is felhasználhatóak legyenek, mégis szerettünk volna egy öszszefüggő egészet alkotni. Ezért az országismereti rész kivételével az egész könyvet átszövi Anna és Peti, egy tinédzser testvérpár története, akik Bécsben születtek, ott is jártak iskolába. Anyukájuk magyar, apukájuk osztrák, ezért mindketten kétnyelvűek. A szülők szeretnék, ha a gyerekek még jobban megtanulnának magyarul, megismernék a magyar kultúrát, a magyar szokásokat. Ezért az egész család Győrbe költözik. Anna

\footnotetext{
2 http://www.nyme.hu/index.php?id=13343\&L=1\&id=13343

${ }^{3}$ A projektről német nyelven a Deutschunterricht für Ungarn, DUFU 2011/1-2. számában, magyar nyelven a Modern Nyelvoktatás 2012. áprilisi számában olvasható részletes elemzés (vö. Einhorn, 2012). Az alább bemutatott taneszközök, kiadványok megtekinthetők és letölthetők az alábbi linken: www.ak.nyme.hu/index. php?id=21057.
} 
és Peti bekerülnek az iskolába, új osztálytársaik lesznek, új barátokat szereznek. Az egész könyv során velük, barátaikkal, ismerőseikkel történt szituációk, események segítségével sajátítják el a tanulók a különféle szituációkban használható mondatokat és kifejezéseket. A könyvben öt nagy témát dolgoztunk ki:

1. Bemutatkozás, ismerkedés,

2. Család, külső-, belső tulajdonságok,

3. Lakóhely, közlekedés,

4. Bevásárlás, étterem, ünnepek, orvosnál, hobbi,

5. Interkulturális ismeretek (Győr).

Az öt témát a szótár követi, ami alapvetően nem szavakat, hanem mondatokat és kifejezéseket tartalmaz. Mondat- vagy kifejezéstárnak is nevezhetnénk, de funkciójában a nyelvkönyveket követő szótárnak felel meg azzal a különbséggel, hogy a képes oldalak, a gyakorlatok és az ötödik fejezet kivételével minden oldalhoz tartozik fordítási segédlet, ami az adott oldalon előforduló összes mondatot vagy kifejezést tartalmazza, még akkor is, ha azok a tankönyv más oldalain már korábban elöfordultak. Minden fejezetet, de sok esetben alfejezetet is, egy vagy több képes oldal vezet be. Ezek az oldalak egy adott témához felhasználható szavakat tartalmaznak képecskék és illusztrációk segítségével. Az alfejezet a következő három részre tagolható: a jelenetek oldalain az adott alfejezet témájához illő párbeszédek találhatók, a párbeszédeket a tananyag visszatérő figurái folytatják egymással, sokszor bonyolultabb nyelvtani megoldásokat alkalmazva, a variációk az adott témában részletesebb és alaposabb elmélyülést tesznek lehetővé, a gyakorlatok oldalain az adott alfejezetben elsajátítandó szavakhoz, mondatokhoz vagy egyszerübb nyelvtani jelenségekhez találhatók feladatok. A nyelvvel együtt interkulturális ismeretet is közvetítünk (Győr) a tanulóknak. Mindez elősegíti bennük a magyarokhoz, Magyarországhoz és annak kultúrájához való pozitív viszonyulást. A kötetről recenzió jelent meg a Modern Nyelvoktatás 2013. márciusi számában (Árvay, 2013).

\subsection{Regionális Nyelvi Portfólió: Magyar mint idegen nyelvi portfólió a 6-10 éves korosztály számára}

Amennyiben a sikeres nyelvtanulás központi értelmezéséből indulunk ki, akkor „nyelvi fejlődésükért" maguk a nyelvtanulók is felelősek. A nyelvtanulás maga egész életen át tartó folyamat, melynek dokumentálása nem csak egy-egy életszakaszra korlátozódik, hanem az egész életet végigkíséri. Ebből kiindulva az Európa Tanács nyelviportfoliókoncepciót dolgozott ki. 1996 óta több Európai Unió által támogatott projekt (CERNET 1996-2004, EdQ 2004-2007) dolgozott ki és jelentetett meg a közép-európai régió különböző iskolás korosztályai (10-15 évesek, 14+ évesek) számára készült angol és német nyelvű európai nyelvi portfóliókat, melyeket az Európa Tanács értékelt és akkreditált. A fent bemutatott modultankönyvhöz szorosan kapcsolódik az Európa Tanács által akkreditált Regionális Nyelvi Portfólió 4 magyar nyelvű változata, amely a nyelvi fejlődés és tapasztalatok dokumentálására szolgál a 6-10 éves korosztály számára.

Az Európai Nyelvi Portfólió végigkíséri a nyelvtanulást az iskolás évek kezdetétől és arra ösztönöz, hogy a kisdiák gondolkodjon el a nyelvi-kulturális sokféleségröl és a különbségekről. A nyelvi portfólió három részből áll:

1. A Nyelvi életrajz a különböző nyelvekről és kultúrákról késztet gondolkodásra, és végigkíséri a nyelvtanulást.

2. A Nyelvi kincsesládában a nyelvtanulás dokumentumait gyűjthetik össze.

\footnotetext{
${ }^{4}$ http://www.nyme.hu/fileadmin/dokumentumok/atfk/edtwin/konyv/85994317_portfolio.pdf
} 
Tartalomalapú nyelvtanulás és -oktatás a korai szakaszban: innovatív tananyagok,...

3. A Nyelvi útlevél nyelvtudással kapcsolatos adatokat tartalmaz mások számára, körülbelül négy év nyelvtanulás után. A kisdiák bemutathatja vele, mi mindent tud a tanult nyelvekből, és milyen tapasztalatai vannak velük kapcsolatban.

A Magyar mint idegen nyelvi portfólió a Nyugat-magyarországi Egyetem Apáczai Csere János Karának mint az EdTWIN-projekt magyarországi partnerének közremüködésével készült.

\subsection{Multimédiaprojekt, 660 perces DVD - Német nyelvtanulás/tanítás dinamikusan}

Harmadik eszközként említhetjük a német nyelv dinamikus tanulása és tanítása érdekében készült Multimédia projekt 660 perces DVD-jét és a hozzá kapcsolódó „Német nyelvtanulás/tanítás dinamikusan” címü kézikönyvet. Ez a kiadványcsomag a német nyelvet tanulóknak és az azt tanítóknak jelent közvetlen szakmai és módszertani segítséget: ötleteket ad a nyelvtanulás kereteinek és tartalmának megújításához német nyelvi lektor, a tanszék és a gyakorlóiskola tanárai és hallgatói, diákjai közremüködésével. A DVD és a kötet az alábbi fejezeteket tartalmazza:

- Kommunikationsspiele - kommunikációs játékok,

- Literaturprojekte - irodalmi projektek,

- Darstellendes Spiel - cselekedtető játékok,

- Ideen für den Lehrer - ötletek a tanároknak,

- Europäische Projekte - Eu-projektek,

- Beispiele aus der Schulpraxis - iskolai példák,

- Beispiele aus der Uni-Praxis - egyetemi példák,

- Jugendsprache in der Centrope-Region, Training - A Centrope-régió ifjúsági nyelve: tréning,

- Sprachenlernen unterstützt von E-learning-Materialien - A Nyelvtanulás segítése e-learninges anyagokkal.

Valamennyi fejezet érdemes a mélyebb tanulmányozásra és gyakorlatba átültetésre. Most azonban „Az egyetemi példák” c. fejezetben megjelenő a Landeskunde im Unterricht - kreativ (Unterrichtsprojekt im IV. Studienjahr) Országismeret a tanórán játékosan - Mikro tanítási formában című részt mutatjuk be röviden. A modul a Célnyelvi kultúrák címü kurzus keretében IV. évfolyamos gyakorló tanítás előtt álló, hallgatók számára mikrotanítási feladat előkészítésével, valamint módszertani követelmények és szakmai háttér megbeszélésével indult és a következő témákhoz készítendő óravázlatokhoz adott instrukciókat: Münchner Oktoberfest, Vom Trabant bis Mercedes, Die Lorelei-Sage, Die Heilige Elisabeth, Märchen von Brüder Grimm, Sissi - ein österreichischer Mythos (két változatban), J. Strauss, der Walzerkönig, Die grössten deutschsprachigen Komponisten, Die Wilhelm Tell-Sage. A fenti témákat a hallgatóknak a 10-12 éves korosztály számára a következő módszertani elvárások alapján mikrotanítási formában kellett prezentálni: kb. 10 perces időkeretben a választott téma felvezetése, változatos, szemléltető, kultúrtörténeti előismereteket felidéző, illetve azt kiegészítő tudás átadása formájában, a kultúrtörténeti téma kapcsán pedig elvárás, hogy az idegen nyelvi kompetencia valamely területeinek fejlesztésére kerüljön sor. A félév során a kurzus keretében saját csoporttársaknak megtartott és videóra vett mikrotanításokat egyéni reflexió és önértékelés követte a következő szempontok alapján: mennyire sikerült a tervezetet a gyakorlatban kivitelezni, a mikrotanítás mely elemeivel elégedett a hallgató, min kellene változtatni és hogyan, majd sor került a csoporttársak feed-backjére, véleményére. Mind az előkészítő, mind az értékelő megbeszélés is része a kb. 180 percet kitevő felvételnek. 
A féléves projekt tapasztalatait összegezve a következőket fogalmazhatjuk meg. Korábbi felfogás szerint az országismeret önálló tantárgy, melyre némelyek szerint csak haladóbb nyelvtanulóknak van szüksége. A Közös Európai Referenciakeret (KER, 2001), mely Európában meghatározza az idegen nyelvek oktatásának alaptanterveit, a nyelvkönyveket, a nyelvvizsgákat - köztük az új érettségit is, részletesen megfogalmazza, mit kell tanulnia minden nyelvtanulónak, hogy egy nyelvet kommunikatív célokra tudjon használni.

A meghatározott kompetenciák közt több is szerepel, például a deklaratív tudás, a nyelvi kompetencia, a szociolingvisztikai kompetencia, melyek az „országismeret” fogalomkörbe tartoznak. Ez a szemlélet a mai elvárásoknak és a modern nyelvpedagógia módszereinek tükrében integrált országismereti koncepciót képvisel. Ezen felfogás értelmében a képzés során elsősorban a cselekvésorientált, kommunikatív, kooperatív és autonóm munkaformákat célszerű előnyben részesíteni. A mikrotanítási projekt gyakorlati kivitelezése pedig szorosan összekapcsolódik az 1990-es évektől előtérbe került kompetenciafejlesztés igényével, és az interdiszciplináris nyelvtanítás gondolatkörével, valamint a fent bemutatott tartalomalapú (CLIL) idegennyelv-tanítás filozófiájával. Mindezen gondolati keretek gyakorlati alkalmazására fejlesztettük ki és sikerrel valósítottuk meg az országismeret tanórai tanításának játékos/kreatív formáját, az ún. mikrotanítást.

\section{Tanulva tanítok - tanítva tanulok: korszerü tanulásszervezési formák és módok}

A továbbiakban az EdTWIN-projekt 2008-2011, és a karon a hallgatói diploma kiadásához szükséges sikeresebb nyelvvizsgázói teljesítmény támogatására létrejött LINGUA 2013-2016 projektek azon fejlesztéseit mutatjuk be, amelyek korszerű tanulásszervezési formát és módot jelentenek a nyelvhasználatot stimuláló és támogató társadalmi-szakmai környezet kialakítására, a szituációban helytálló tudás megélésére és a komplexusmentes nyelvhasználat megtapasztalására, és amelyek a projektek zárása után fenntartható modellként müködhetnek a régióban a közép- és felsőoktatásban tanulók számára 5 .

\subsection{Inter-Cafe és Lingua Klub-programok}

Alkalmankénti klubfoglalkozások, nemzeti estek (Melange Deutsch: Inter- und Multikulturalität, Les repas en France et en Hongrie, Japán a felkelő nap országa, Orosz nyelv és kultúra ma stb. témák) alkalmanként 1-2 óra keretében szerveződnek a témát kínáló nyelvtanár és/vagy szakember, valamint a nyelvet használni szándékozó hallgatók részvételével. A téma valamely input révén (film, prezentáció, előadás, poszter, kiállítás stb.) kerül felvezetésre, majd a moderátor vezetésével kiegészítésre, megtárgyalásra, a résztvevők minél nagyobb aktivitását kiváltva. A modell 2013 tavaszától az Apáczai Karrier Iroda és az Idegen Nyelvi Tanszék Lingua projektje 2013-2017 keretében folytatódik.

\subsection{Kétnyelvű tanulás és tanítás a határ mentén}

Az EdTWIN-projektben a kar és a partnerintézmények angolul és németül tanuló/tudó oktatóinak, pedagógusainak és hallgatóinknak hétvégi bilingvális, angol és német nyel-

\footnotetext{
${ }^{5}$ EdTWIN-projekt beszámolói 2008-2011, Tudósítás és fotók: www.ak.nyme.hu/index.php?id=22909
} 
Tartalomalapú nyelvtanulás és -oktatás a korai szakaszban: innovatív tananyagok,...

vű nemzetközi képzési programot szerveztünk vendégelőadóval, összesen 16 óra időtartamban, melynek elvégzéséről Tanúsítványt állítottunk ki. A program a Kar Idegen Nyelvi és Irodalmi Tanszéke és a Burgenlandi Pedagógiai Főiskola együttmüködésében valósult meg. A megélt és megszerezett bilingvális tapasztalatra és gyakorlatra bátran támaszkodhatnak oktatóink és hallgatóink az ERASMUS és más mobilitási és nemzetközi programok későbbi ösztöndíjas résztvevőjeként (EdTWIN-projekt beszámolói, 2008-2011).

\subsection{Tanítási gyakorlat és hospitálás Bécsben és Eisenstadtban}

Az EdTWIN-projekt keretében tanító szakos hallgatók pályázaton meghirdetett bécsi tanítási gyakorlaton vehettek részt. A gyakorlat helyszíne a többnyelvű és több kultúrájú „Dr. Leopold Zechner Europäische Volksschule” iskola volt, melyben kb. 20 különböző (pl. szerb, horvát, ukrán, török, egyiptomi, afrikai, arab, koreai stb.) nemzetiségű gyermek tanul. A legfontosabb jellemzők, amelyek meghatározzák az intézményben folyó oktatási-nevelési munkát: többnyelvűség (nyelvi mühelyek, anyanyelvoktatás), teammunka, reformpedagógiák (pl. Montessori) alapján való tanítás, projektek, kreativitás, alternatív teljesítményértékelési formák. A hospitáláson résztvevők - a célnyelvi környezet adta előnyökön kívül - rendkívül sok módszertani ötletet, játékot és tapasztalatot szereztek, és tudatosan gyűjtöttek a Bécsben eltöltött egy hét során. Alkalmuk volt a fent említett modultankönyvet használva magyar nyelvi órákat tartani az iskola érdeklődő diákjainak. Tapasztalataikat adott szempontok szerint Tanulmányi naplóban reflektálták. Visszajelzéseik szerint maradandó nyomot hagyott bennük ez a hét, és nagyban hozzájárult a nyitott szemléletű oktatómunka megkezdéséhez. Ilyen és ehhez hasonló szakmai tanulmányutak a továbbiakban az ERASMUS és más mobilitási programok révén lehetségesek (EdTWIN-projekt beszámolói, 2008-2011). A jó kapcsolatot fenntartva és a jelenlegi LINGUA projekt célkitüzéseit figyelembe véve 2013-ban folytatódnak a tanító szakos hallgatók egy-egy napos tanulmányútjai, melyeket hallgatóink nyelvi kompetenciáinak és módszertani tudásának támogatására szervezünk a bécsi Európai Iskola multikulturális és multilingvális iskola alsó tagozatos osztályaiban. Ezek az iskolalátogatási programok összekapcsolódnak a német nyelvi képzésben részt vevő tanítók célnyelvi kultúra kurzusának azon célkitüzésével, hogy a hallgatók megismerjék Bécs nevezetességeit 6 .

A kar németül tanuló tanító, gyógypedagógus és andragógus hallgatói és oktatóik ugyancsak tanulmányúton jártak a burgenlandi Pedagógiai Főiskolán. Német nyelvủ előadást hallottak Erziehungswissenschaft címmel Univ.-Doz. Dr. Dr.h.c. Johann Pehofer előadásában. A délután folyamán megismerkedtek és konzultáltak a főiskola tanító szakos hallgatóival, akik „Sternenstaub und Regenbogen“ c. projektjüket mutatták be hét workshop keretében. Az eisenstadti hallgatók projektnapok keretében környező világunk és a természet újszerű megközelítésére adnak módot és ötleteket burgenlandi iskolák diákjainak. A győri hallgatók ezt követően német nyelvű városnézésen ismerkedtek Eisenstadt kulturális értékeivel, közös történelmünk eseményeivel7

\subsection{Nyelvi asszisztensek regionális programokon}

Az EdTWIN-projekt és a Krúdy Gyula Gimnázium, Két Tanítási Nyelvű Középiskola, valamint a Nemzetiségi Iskola Kimle közös szervezésében több éve megrendezzük az osztrák

\footnotetext{
6 Tudósítás és fotók: www.ak.nyme.hu/index.php?id=10624

7 Tudósítás és fotók: www.ak.nyme.hu/index.php?id=22909.
} 
vers és próza ünnepét, a német nyelvű irodalom barátainak találkozóját. A vers- és prózamondó versenyen több kategóriában az 1-2., 3-4., 5-6., 7-8., illetve 9-12. évfolyamos tanulók közül azok vettek részt, akik magas óraszámban vagy nemzetiségi nyelvként tanulják a német nyelvet. A kb. 120 versenyző nemcsak a választott verset adta elő, hanem bemutatta a költemény szerzőjét és a vers gondolati tartalmát is. A legjobb versenyzők oklevelet és tárgyi jutalmat kaptak, mellé bécsi terepgyakorlaton vehettek részt. A tanító szakos hallgatókat nyelvi asszisztensként vontuk be a verseny lebonyolításába és a zsüri munkájába. Az asszisztenseknek - a nyelvi teljesítményen túl - alkalmuk volt pedagógiai feladatokat végezni, így szakmai felkészülésüket is szolgálta a program².

\subsection{Több nyelv - több esély. Miniinterjúk a győri belvárosban}

2012 őszén került megrendezésre a Nyugat-magyarországi Egyetem Apáczai Csere János karának „Apáczai Agora - Életképek” című rendezvénye. A kar bemutatását célul tǔző programnak Győr legforgalmasabb sétálóutcája adott otthont. A rendezvény során a járókelők megannyi aspektusból ismerhették meg a karon folyó sokszínű képzési kínálatot. A központi színpad melletti pavilonokban pedig az egész rendezvény ideje alatt interaktív társasjáték, pályaorientációs teszt, báb- és koktélkészítés stb. várta az érdeklődőket. Az Agora-rendezvény azonban nemcsak a színpadon és körülötte zajlott. A kar tanító és más szakos hallgatói (kb. 60 fő) a környező utcákban idegen nyelv(ek) en interjúvolták a járókelőket. A feladat lényege: a hallgatók a karon és a workshopokon megszerzett nyelvtudásukat a gyakorlatban alkalmazva, a járókelőkkel párbeszédbe elegyedve, térképezzék fel a lakosság nyelvismeretét. Az Idegen Nyelvi Tanszék által koordinált programot követően a hallgatók az interjúk során szerzett tapasztalatukat röviden értékelték. A visszacsatolásokból kiderült, hogy pár óra alatt kb. 340 interjút kezdeményezett a kb. 60 hallgató, melyek kb. 50\%-ban zárultak sikeres, kétoldalú, idegen nyelvű kommunikációval. Az interjút kezdeményezők a megszólítottakat nyelvtanulásuk, nyelvhasználatuk, utazási tapasztalataik, foglalkozásuk felől kérdezték a tanszéken oktatott nyelveken, így angolul, németül, franciául, spanyolul, olaszul, oroszul és japánul, valamint a szomszéd országok nyelvén, horvátul, szlovákul és csehül, de kuriózumként megjelent a holland, az eszperantó és a lovari nyelv is. Az interjúkészítők kiemelték, hogy a megkérdezett járókelők által leginkább ismert két nyelv az angol és a német volt, az egyéb nyelveken, például franciául és spanyolul indított próbálkozások kevésbé jártak sikerrel. A kérdezők közös tapasztalata továbbá, hogy föként a fiatalok mutatkoztak kommunikatívabbaknak, az idősebb korosztály sokszor inkább elnézést kérve továbbállt. A visszajelzésekböl kiderült az is, hogy a hallgatók a feladatot hasznosnak ítélték, mert saját nyelvtudásukat, kapcsolatteremtő képességüket éles helyzetben próbálhatták ki, ezt sokan kihívásként élték meg. Ugyanakkor a válaszolók - sok esetben - hiányos nyelvismerete tudatosította bennük az idegen nyelvek tanulásának, használatának fontosságát, és azt is, hogy céltudatosabban, gazdaságosabban és felelősségteljesebben kell a nyelvtanulásra fordított időt, pénz és energiát kezelni, a megszerzett nyelvtudást pedig értéknek kell tekinteni, amellyel személyes és szakmai kapcsolatokra lehet szert tenni. Már ezért a felismerésért érdemes volt az interjúk készítésére vállalkozni. Az „Apáczai Agora - Életképek" rendezvényröl pedig örömmel mondhatjuk, hogy egy hangulatos színfoltja volt Győr életének, ahol a Kar egésze képviseltette magát, és változatos, egyedi módon mutatta be az egyetemen folyó képzést.

\footnotetext{
${ }^{8}$ Az EdTWIN - projekt 2008-2011 beszámolói megtekinthetők: www.ak.nyme.hu/index.php?id=13343
} 


\subsection{Nokia projekt 2012-2013 nyelvi gyakornokokkal}

A Nokia Rt. aktuális szlogenje 2012-ben akár a "leépítés és tanulás” is lehetett volna. Miközben a cég nagy létszámú leépítést hajtott végre komáromi telephelyén,egyúttal a társadalmi felelősségvállalás egy sajátos formáját alkalmazta: a Nyugat-magyarországi Egyetem Apáczai Csere János Karával létrejött képzési kooperáció keretében mintegy 70 munkatársa számára 14 hetes (30 órás) angol nyelvtanfolyam megszervezésére és megtartására kérte fel az Idegen Nyelvi és Irodalmi Intézeti Tanszék oktatóit és angol nyelvoktató képzésben részt vevő tanító szakos hallgatóit9. A képzési együttműködés egyenes folytatása volt a 2008-2011 között ugyancsak a kar és a tanszék által koordinált és megvalósított EdTWIN-projekt nyelvi asszisztensi programjának. A gyakornoki program továbbfejleszti a nyelvi asszisztensi programot és nagyszerü lehetőséget kínál a programban résztvevő hallgatóknak, hiszen a tanszéken folyó elméleti képzéssel párhuzamosan - akciókutatásként felfogva azt - azonnal a gyakorlatban is kipróbálhatják, kamatoztathatják nyelvi és szakmai tudásukat, és mint gyakornokok nagyszerü tanítási tapasztalatot szerezhetnek, miközben sajátos képzési programban vesznek részt. A Nokia Projekt 2012 februárjában kezdődött, első szakasza május végéig tartott, majd októbertől folytatódott. A gyakornok-hallgatók Dr. Helen Sherwin adjunktussal, a tanszék oktatójával a projekt angol anyanyelvű szakmai mentorával álltak folyamatos kapcsolatban. Felkészülésüket, szakmai munkájukat a kari, ún. Moodle internetes keretrendszer támogatja, amelynek fórumfelületén ötleteket, anyagokat, módszereket cserélhetnek, tanácsokat kaphatnak, közösen gondolkodhatnak a felmerülő szakmai-metodikai-didaktikai kérdések megoldásán, megoszthatják tapasztalataikat és élményeiket. Munkájukat kurzusszervező koordinátor is segíti. A gyakornok-hallgatók pályázat útján és szóbeli (nyelvi-módszertani szempontokat felvető) interjú alapján kerültek a programba, a kb. 30 pályázóból 13 fő kapott lehetőséget a megmérettetésre. Az alábbi linken elérhető az első tapasztalatokat nyilvánosan megosztó videofelvétel „Apáczais segítő jobb a Nokiának”10. (Bár 2013. januártól közösen dolgoztunk a Nokia Komárom Rt. képviselőivel a projekt továbbfejlesztésén és folytatásán, ez a lehetőség a komáromi gyár bezárásával megszűnt. Folytatás a Győr-Moson-Sopron Megyei Kereskedelmi és Iparkamarában működő, kisvállalkozásokat tömörítő Professzió Klaszter csoporttal 2015-ben kezdett tárgyalások alapján lehetséges.)

\subsection{Kistanítók bevetésen - mikrotanítás kimlei kisdiákoknak}

2013 februárjában a kimlei Nemzetiségi Általános Iskola kisdiákjai látogattak el a NMYE Apáczai Kar Idegen Nyelvi Tanszékére, hogy „kistanítónénik” - mint gyakornokok - vezetésével német nyelvü dalokat tanuljanak, nyelvi akadályversenyen vegyenek részt. $A$ program a német nyelvű műveltségterületi képzésben részt vevő másodéves tanítóképzős hallgatóknak enged bepillantást a pedagógusszakma rejtelmeibe, élő iskolai partnerkapcsolatok révén. A korábban iskolai rendezvényeken, versenyeken végzett nyelvi asszisztensi és gyakornoki munka számos pozitív gyakorlati tapasztalattal szolgált a képzősök nyelvi-pedagógiai-módszertani felkészítésében, kiegészítette és formálta azt. Az elméletben tanultakat a tanító pályára készülő hallgatók új lehetőségként - mikrotanításnak is felfogható - igazi gyakorlóterepen, általános iskolai tanulókkal, tanórán kívül, sajátos körülmények között próbálhatják ki. A kezdeményezés a képzős hallgatók pedagógusi hivatástudatának alakítását és elmélyítését nagymértékben segítette ${ }^{11 .}$

\footnotetext{
9 A NOKIA projekt beszámolója (2012. tavasz) itt olvasható: www.ak.nyme.hu/index.php?id=24279

10 HÍRCITY 2012: www.hircity.hu/tudaster/209506

${ }^{11}$ A fotók megtekinthetők: www.ak.nyme.hu/index.php?id=10624
} 


\section{Összegzés}

Az Idegen Nyelvi és Irodalmi Intézeti Tanszék huszonöt éves fennállása óta folyamatosan figyelemmel kíséri, segíti és műveli is az innovatív gondolatok születését, megvalósulását. Irányadónak tekintjük az idegen nyelvoktatásban érvényesülő nyelvpedagógiai tendenciákat, különös tekintettel a Közös Európai Referenciakeret (KER, 2001) ajánlásaira, amelyek a tartalom- és kompetenciaalapú (Content and Language Integrated Learning, CLIL) nyelvi közvetítésre és többnyelvűségre, az interkulturális tanulásra, a használható nyelvtudásra helyezik a hangsúlyt. A fentiekben - ezek szellemében - bemutattunk néhányat az osztrák-magyar bilaterális EdTWIN-projektben (2008-2011) kifejlesztett, kipróbált és használatra közreadott innovatív tananyagok és -eszközök, valamint tanulásszervezési formák és módok közül, melyeket szervesen beépítettünk az angol-német választott műveltségterületen folyó tanítóképző tevékenységünkbe, illetve fenntartásuk és továbbfejlesztésük érdekében dolgozunk velük a kari idegen nyelvi stratégia LINGUA 2013-2016 akcióprogramjában. Tesszük mindezt annak reményében, hogy a pedagógiai kérdéseken túl sikerül stimuláló és támogató nyelvi környezetet teremteni, és így a nyelvtanuló attitűdjét pozitív irányban változtatni, annak megértésére és megélésére, hogy a nyelvtanulás kockázatvállaló befektetés, de egyben örömforrás is, amely a szakmai és személyes életet is gazdagíthatja.

\section{Felhasznált irodalom}

Árvay Anett (2013): Farkas Tímea-Kellerer-Egerszegi Kriszina: Kincskeresők, kalandra fel! Győr: Nyugat-magyarországi Egyetem Kiadó, 2011. 149 p. ISBN 978-963-334-034-9. Modern Nyelvoktatás, 19. 1-2. sz., 108-110.

Common European Framework of Reference for Languages: Learning, Teaching. Assesment. Starsbourg: Council of Europe, 2001.

URL: http://www.nyak.hu/nyat/doc/ker_2002.asp

Coyle D. \& Hood Ph. \& Marsh D. (2010): Content and Language Integrated Learning. CUP, Cambridge.

Europeans and their Languages (2006): European Comission, Eurobarometer.

URL: http://ec.europa.eu/public_opinion/archives/ebs/ebs_243_en.pdf. Letöltés ideje: 2014. február 6.

EdTWIN projektterv (2008): - Education Twinning for European Citizenship Heading for Excellence in the CENTROPE REGION - Ikerkapcsolatok az oktatásban. Centrope Régió vezető iránya. Ausztria-Magyarország Határon Átnyúló Együttmüködési Program 2008-2011. Projektterv 2008, Projektszám: L00048/HU. Győr, kézirat.

EdTWIN projekt beszámolói (2008-2011) - Education Twinning for European Citizenship Heading for Excellence in the CENTROPE REGION. Ikerkapcsolatok az oktatásban. Centrope Régió vezető iránya. Ausztria-Magyarország Határon Átnyúló Együttmüködési Program 20-082011, Projektszám: L00048/HU. Györ, kézirat.

URL: www.ak.nyme.hu/index.php?id=21583\&L=1\&id=21583. Szakmai jelentések AP1-AP4, 2008-2010. Letöltés ideje: 2014. február 6.

Einhorn Ágnes (2012): Nyelvtanításunk eredményessége nemzetközi tükörben. Modern Nyelvoktatás, 18. 3. sz., 22-35.

Görcsné Muzsai Viktória (2012): Határtalan kommunikáció és kooperáció a Centrope Régióban. In: Horváthné Molnár Katalin ésAntonio Donato Sciacovelli (szerk.) MANYE XXXI. Kongresszus, Szombathely. MANYE - NYME, Budapest-Szombathely-Sopron, 339-344.

URL: http://www.kjf.hu/manye/2011_szombathely/kotet/43_gorcsne.pdf

Görcsné Muzsai Viktória (2012): Leben und Arbeiten in der Centrope Region kompetent. Grenzüberschreitende Kontakte für die europäische Bürgerschaft 
durch das EdTWIN-PROJEKT. In: DuFu, Budapest, 2011 december, 29-46. URL: http://www.scribd.com/doc/109211817/5/Leonore-Peer

Günther, B. \& H. (2005): Frühe Fremdsprachen im Kindergarten. Ernst Klett, Stuttgart.

Freudenstein, R. (1997): Success of Differing Approaches to Language Learning. In B. Kettemann \& I. Landsiedler \& D. Heindler \& J. Huber \& E. Jantscher (Eds.), The Effectiveness of Language Learning and Teaching - Ergebnisse der Europaratstagung vom 5.-8. März 1996 in Graz. (= ZSE Report 27). Graz, Zentrum für Schulentwicklung, $69-77$.

Képzés határok nélkül (2011): Kerekasztal beszélgetés az EdTWIN 2008-2011 projekt eredményeiröl, tapasztalatairól, produktumairól és a fenntarthatóság perspektíváiról. Vivat Academia, a Nyugat-magyarországi Egyetem lapja, 6, 24-25.

Peltzer-Karpf, A. \& Zangl R. (1998): Die Diagnose des frühen Fremdsprachenerwerbs. Narr, Tübingen.

Medgyes Péter (2010): Szépe György - a véletlenek embere. Modern Nyelvoktatás, 16. 2-3. sz., 84.

\section{Linkek:}

Apáczais segítő jobb a Nokiának (video):

URL: http://www.hircity.hu/tudaster/209506. Letöltés ideje: 2012. április 03.

EdTWIN projekt kiadványai:

URL: www.ak.nyme.hu/index.php?id=21057. Letöltés ideje: 2013. május 25.

Kistanitók bécsi hospitálása 2013. április 11., tudósítás és fotók:

URL: www.ak.nyme.hu/index.php?id=10624. Letöltés ideje: 2013. május 25.

Lingua Klub, tudósítás és fotók.

URL: www.ak.nyme.hu/index.php?id=22909. Letöltés ideje: 2013. május 25.

NOKIA projekt beszámolója 2012 tavaszi félév. Apáczai Kar archívuma, kézirat. URL: bin/hircity/index.cgi?view=ck\&tID=614\&nID=209506\&nyelv=hu Letöltés ideje: 2013. január 11.

Tanitók, gyógypedagógusok és andragógusok az eisenstadti pedagógiai föiskolán, tudósítás és fotók. URL: www.ak.nyme.hu/index.php?id=22909. Letöltés ideje: 2013. május 25. 